\title{
CHARACTERIZATION AND HARDNESS OF Co-P COATINGS OBTAINED FROM DIRECT CURRENT ELECTRODEPOSITION USING GLUCONATE BATH
}

\section{H. SEENIVASAN ${ }^{\mathrm{a}, \mathrm{c}}$, PARTHASARATHI BERA ${ }^{\mathrm{a},{ }^{*}}$, K. S. RAJAM ${ }^{\mathrm{a}}$, SANJIT KUMAR PARIDA ${ }^{b}$}

${ }^{a}$ Surface Engineering Division, CSIR-National Aerospace Laboratories, Bangalore 560017, India

${ }^{b}$ Solid State and Structural Chemistry Unit, Indian Institute of Science, Bangalore 560012, India

\begin{abstract}
Direct current electrodeposition of Co-P alloy coatings were carried out using gluconate bath and they were characterized by employing techniques like XRD, FESEM, DSC and XPS. Broad XRD lines demonstrate the amorphous nature of Co-P coatings. Spherical and rough nodules are observed on the surface of coatings as seen from FESEM images. Three exothermic peaks around 290,342 and $390{ }^{\circ} \mathrm{C}$ in DSC profiles of Co-P coatings could be attributed to the crystallization and formation of $\mathrm{Co}_{2} \mathrm{P}$ phase in the coatings. Asdeposited coatings consist of Co metal and oxidized Co species as revealed by XPS studies. Bulk alloy $\mathrm{P}\left(\mathrm{P}^{\delta-}\right)$ as well as oxidized $\mathrm{P}\left(\mathrm{P}^{5+}\right)$ are present on the surface of coatings. Concentrations of Co metal and $\mathrm{P}^{\delta-}$ increase with successive sputtering of the coating. Observed microhardness value is $1005 \mathrm{HK}$ when Co-P coating obtained from 10 $\mathrm{g} \mathrm{L}^{-1} \mathrm{NaH}_{2} \mathrm{PO}_{2}$ is heated at $400{ }^{\circ} \mathrm{C}$ that is comparable with hard chromium coatings.
\end{abstract} Keywords: Alloy coating; Co-P; Electrodeposition; DSC; XPS; Microhardness;

*Corresponding author

Tel: +91-80-25086359, Fax: +91-80-25210113, E mail: partho@nal.res.in (P. Bera) 
${ }^{c}$ Present address: Department of Chemical Sciences, Indian Institute of Science Education and Research Kolkata, Mohanpur 741252, West Bengal, India

\section{Introduction}

In recent years, Co and Co based alloys have been identified as unique materials in replacing of hard chromium coatings that are formed in the environmentally hazardous

process based on hexavalent chromium. ${ }^{1-6}$ It has also been found that alloying with $\mathrm{P}$ enhances the wear behavior, corrosion behavior, thermal stability and electrochemical properties of nanocrystalline and amorphous $\mathrm{Co}^{7-12}$

Electrodeposition has been considered as a simple, economical and viable method to prepare high quality alloy coatings. ${ }^{13,14}$ Brenner had first introduced electrodeposition of Co-P alloys. ${ }^{15}$ Previously, chloride and sulfate baths were employed to prepare these alloy coatings. Conditions of electrodeposition also play a significant role in composition, structure and properties of these coatings. Generally, many carboxylate based complexing agents such as citrates, sulfamates, tartrates, malates, glycinates and gluconates were being used in the process of electrodeposition of various metals and their alloys. These complexing agents are easily obtainable and nontoxic to aquatic organisms. Weston et al. used gluconate bath for the electrodeposition of $\mathrm{Co}-\mathrm{W}$ coatings. ${ }^{16}$ Recently, we have reported studies on pulse electrodeposited $\mathrm{Co}-\mathrm{P}$ coatings employing gluconate bath. ${ }^{17}$ In this sense, we wanted to see the differences in structure and properties of $\mathrm{Co}-\mathrm{P}$ coatings prepared with direct current (DC). In the present study, we report DC electrodeposition of Co-P coatings using gluconate bath of different $\mathrm{P}$ content. X-ray diffraction (XRD), field emission scanning electron microscopy (FESEM), energy dispersive X-ray spectroscopy 
(EDXS), differential scanning calorimetry (DSC) and X-ray photoelectron spectroscopy (XPS) techniques are used to characterize the surface structure, morphology, thermal study, composition and elemental oxidation states of coatings. Structure and microhardness of these alloy coatings before and after heat treatment has been investigated to study the coating characteristics.

\section{Experimental methods}

Co-P alloy coatings were electrodeposited from a bath containing cobalt sulfate heptahydrate $\left(15 \mathrm{~g} \mathrm{~L}^{-1}\right)$, boric acid $\left(40 \mathrm{~g} \mathrm{~L}^{-1}\right)$, sodium gluconate $\left(110 \mathrm{~g} \mathrm{~L}^{-1}\right)$ and sodium

chloride $\left(30 \mathrm{~g} \mathrm{~L}^{-1}\right)$. The $\mathrm{pH}$ of bath was around 5.2 and the $\mathrm{pH}$ was adjusted to $5.0 \pm 0.05$ by the addition of $\mathrm{H}_{2} \mathrm{SO}_{4}$. Three different $\mathrm{Co}-\mathrm{P}$ alloy coatings with varying $\mathrm{P}$ content were obtained by adding 2, 5 and $10 \mathrm{~g} \mathrm{~L}^{-1} \mathrm{NaH}_{2} \mathrm{PO}_{2}$ into the above prepared bath. Here, $\mathrm{NaH}_{2} \mathrm{PO}_{2}$ was used as a $\mathrm{P}$ source. Analytical grade chemicals and deionized water were used to prepare the baths. For electrodeposition, approximately $200 \mathrm{~mL}$ solution was taken in a $250 \mathrm{~mL}$ glass beaker. Temperature of the bath was maintained at $80{ }^{\circ} \mathrm{C}$ using a constant temperature water bath. A graphite bar was used as the anode and a mechanically buffed brass sheet with $10 \mathrm{~cm} \times 2.5 \mathrm{~cm} \times 0.1 \mathrm{~cm}$ dimension with an exposed area of $6.45 \mathrm{~cm}^{2}$ was used as the substrate. The graphite anode was covered with a pretreated anode bag which prevented the carbon depositing on the Co-P coatings. For XPS and DSC studies plating was done on stainless steel substrates and peeled off from the substrate for analysis. Substrate was degreased with acetone, rinsed with tap and deionized water, cathodically cleaned with $10 \% \mathrm{NaOH}$ solution for $1 \mathrm{~min}$ at $15 \mathrm{~A} \mathrm{dm}^{-2}$, rinsed with tap and deionized water. Then the substrate was deoxidized with 10 vol.\% $\mathrm{H}_{2} \mathrm{SO}_{4}$ for $30 \mathrm{~s}\left(50\right.$ vol.\% $\mathrm{H}_{2} \mathrm{SO}_{4}$ for $5 \mathrm{~s}$ for stainless steel substrate), rinsed with tap 
water and deionized water and loaded in the bath for electroplating. DC electrodeposition was carried out galvanostatically by using an Aplab 7253 regulated DC power supply at an average applied current density of $4.7 \mathrm{~A} \mathrm{dm}^{-2}$. The plating was carried out for $1 \mathrm{~h}$ and the deposited coating was rinsed with deionized water and dried at room temperature. The current efficiencies of the deposits have been evaluated using Faraday's first law of electrolysis assuming electrochemical equivalence of $0.000305 \mathrm{~g} \mathrm{C}^{-1}$ for $\mathrm{Co}-\mathrm{P}$.

The heat treatment temperatures were identified and chosen from DSC curves. Co-P alloy coatings were heat-treated for $1 \mathrm{~h}$ in a muffle furnace. To prevent the oxidation of the coating a paste of proprietary mixture was applied on the coated samples. This was then dried and wrapped in a nickel foil and introduced into the furnace when the required temperature was attained. Coating obtained from the bath containing $2 \mathrm{~g} \mathrm{~L}^{-1}$ $\mathrm{NaH}_{2} \mathrm{PO}_{2}$ was heat treated at 280 and $400{ }^{\circ} \mathrm{C}$ while the other two high phosphorous containing coatings prepared with baths containing 5 and $10 \mathrm{~g} \mathrm{~L}^{-1} \mathrm{NaH}_{2} \mathrm{PO}_{2}$ were annealed at 300 and $400{ }^{\circ} \mathrm{C}$. The accuracy of the set temperature was $\pm 10{ }^{\circ} \mathrm{C}$. Rates of heating and cooling were $5{ }^{\circ} \mathrm{C} \min ^{-1}$.

The structure of alloy deposits was determined by XRD studies employing a PANalytical X'Pert PRO X-Ray diffractometer operated with $\mathrm{CuKa}$ radiation of 1.5418 $\AA$ wavelength at $40 \mathrm{kV}$ and $30 \mathrm{~mA}$ in the $2 \theta$ range $30-100^{\circ}$.

The surface morphology and composition of these alloy coatings were examined by FESEM using a Carl Zeiss Supra 40VP coupled with energy dispersive X-ray spectrometer from Oxford Instruments. 
Surface roughness was investigated by AFM from CSEM Instruments (Model SSI) operated in non-contact mode and calculated from average roughness $\left(\mathrm{R}_{\mathrm{a}}\right)$ and root mean square roughness $\left(\mathrm{R}_{\mathrm{rms}}\right)$ values.

DSC studies for the phase transformation of these Co-P alloy coatings were performed with a Diamond DSC (Perkin Elmer) at the heating rate of $20{ }^{\circ} \mathrm{C} \mathrm{min}^{-1}$ under continuous purging of the heating chamber with nitrogen flow of $30 \mathrm{~mL} \mathrm{~min}{ }^{-1}$ to avoid sample oxidation. The plot of temperature against heat flow was obtained.

XPS of several electrodeposited Co-P alloy coatings were recorded with a Thermo Fisher Scientific Multilab 2000 spectrometer using non-monochromatic AlKa radiation $(1486.6 \mathrm{eV})$ run at $15 \mathrm{kV}$ and $10 \mathrm{~mA}$ as $\mathrm{X}$-ray source. The binding energies $\left(\mathrm{E}_{\mathrm{B}}\right)$ reported here were calculated with reference to $\mathrm{C} 1 \mathrm{~s}$ peak at $284.5 \mathrm{eV}$ with a precision of $\pm 0.1 \mathrm{eV}$. All the spectra were obtained with pass energy of $30 \mathrm{eV}$ and step increment of $0.05 \mathrm{eV}$. To know composition and elemental oxidation states, coating surface was sputtered with defocussed $\mathrm{Ar}^{+}$ion beam using EX05 ion gun fitted in the preparation chamber by applying energy of $3 \mathrm{keV}$ and beam current of $2.6 \mu \mathrm{A}$ with $\mathrm{Ar}$ gas pressure of $5 \times 10^{-6}$ Torr. Sputtering rate was $5 \mathrm{~nm} \mathrm{~min}{ }^{-1}$. The experimental data were curve fitted with Gaussian peaks after subtracting a linear background employing PeakFit v4.11 program. For Gaussian peaks, slightly different full width at half maximum (FWHM) was used for different chemical states. The spin-orbit splitting and doublet intensities were fixed as given in the literature. ${ }^{18}$

Microhardness measurements of these alloy coatings were carried out on the surface of the deposits using Buehler microhardness tester (Micromet 100) with a Knoop indenter under a test load of $50 \mathrm{~g}$ for $15 \mathrm{~s}$. For microhardness measurements, samples 
were polished with $0.3 \mu \mathrm{m} \mathrm{Al}_{2} \mathrm{O}_{3}$ until mirror finishing was obtained. Average hardness (HK) value was estimated by making 5 indents on each sample.

\section{Results and discussion}

\subsection{Current efficiencies, deposition rates and chemical compositions}

Current efficiencies for DC plated Co-P alloys calculated from the charge passed and the weight gained are observed to be $62 \pm 5 \%$, whereas deposition rates of these alloys leads to thickness of $36 \pm 2 \mu \mathrm{m} \mathrm{h}^{-1}$. Lin et al. found concomitant decrease in current efficiency with the increase in phosphorous content in the alloy when the plating mode was changed from DC plating to pulse plating. ${ }^{19}$ This is true in our case as we see the current efficiency in DC plating is high when compared to that obtained from the pulse plating under the same conditions. ${ }^{17}$ This can be because of the peak current density used in pulse plating i.e. $23.5 \mathrm{~A} \mathrm{dm}^{-2}$ which might be above the limiting current density for this system.

Amounts of $\mathrm{P}$ are observed to be 11.6, 13.6 and 13.7 at.\% in Co-P coatings prepared with 2, 5 and $10 \mathrm{~g} \mathrm{~L}^{-1} \mathrm{NaH}_{2} \mathrm{PO}_{2}$, respectively as determined by EDXS and corresponding spectra are shown in Fig. 1. EDX spectra confirm the absence of trace amount of carbon content in the coatings which was presumed to be contaminated from the graphite bar anode. It is evident that even with smaller concentration of hypophosphite $\left(2 \mathrm{~g} \mathrm{~L}^{-1}\right)$ in the bath we were able to produce electrodeposit with high $\mathrm{P}$ concentration containing 11.5 at.\%. P content while it increases to 13.6 at. $\%$ when $5 \mathrm{~g}$ $\mathrm{L}^{-1} \mathrm{NaH}_{2} \mathrm{PO}_{2}$ is added and there is no appreciable change in $\mathrm{P}$ concentration with further increase in the hypophosphite concentration indicating that high $\mathrm{P}$ content amorphous 
coating could be obtained from gluconate bath using small amount of $\mathrm{P}$ precursor at a relatively high temperature. It is important to note that there is a relation between the magnitude of the DC current density and the amount of phosphorous content. The relationship can be shown by calculating the partial current densities for Co and $\mathrm{P}$ during the electrodeposition process. The partial current density $\left(i_{\text {metal }}\right)$ is calculated by the following formula:

$$
i_{\text {metal }}=\frac{-n F M_{\text {deposit }} W_{\text {metal }}}{\text { at } M_{\text {metal }}} \mathrm{A} \mathrm{m}^{-2}
$$

where, $\mathrm{n}, \mathrm{F}, \mathrm{M}_{\text {deposit }}, \mathrm{W}_{\text {metal }}, a, \mathrm{t}$ and $\mathrm{M}_{\text {metal }}$ are valency of the metal atom, Faraday constant $\left(96485 \mathrm{C} \mathrm{mol}^{-1}\right)$, mass (g) of the deposit, weight percent of the metal in the alloy deposit, reactive surface area $\left(\mathrm{m}^{2}\right)$ of the deposit, time (s) duration of the deposition, and molecular weight $\left(\mathrm{g} \mathrm{mol}^{-1}\right)$ of the metal, respectively. The ratio $\left(\mathrm{R}_{\mathrm{i}}\right)$ of the partial current density $\left(i_{C o}\right.$ or $i_{P}$ ) for the deposition of cobalt or phosphorous to the total current density $\left(i_{T}\right)$ were calculated according to reference $19 . R_{i}$ values of Co are $0.526,0.518$ and 0.518

for 2, 5 and $10 \mathrm{~g} \mathrm{~L}^{-1} \mathrm{NaH}_{2} \mathrm{PO}_{2}$, respectively, whereas these values for $\mathrm{P}$ are $0.068,0.082$ and 0.082 . Therefore, comparison of the $\mathrm{R}_{\mathrm{i}}$ values obtained for the deposition of Co and $P$ demonstrates that there is a very small change in the $R_{i}$ values for different concentrations of $\mathrm{NaH}_{2} \mathrm{PO}_{2}$ which indicates that there is no appreciable change in the content of Co or $\mathrm{P}$ with changing phosphorous source.

\subsection{XRD studies}

XRD patterns of as-deposited Co-P alloy coatings with different $\mathrm{P}$ content are given in Fig. 2 (a). XRD pattern of coatings demonstrates the presence of the structure of major component of the alloy. Accordingly, a broad peak around $44.9^{\circ}$ observed for all the 
Co-P alloy coatings demonstrates that the deposits are amorphous in nature. Peak intensities in all samples are more or less same. Specifically, the peak positions show a very small shift from the usual value. Co-P with $2 \mathrm{~g} \mathrm{~L}^{-1} \mathrm{NaH}_{2} \mathrm{PO}_{2}$ shows the peak at $45.1^{\circ}$ while the peak was seen at $44.8^{\circ}$ for the Co-P coating prepared at 5 and $10 \mathrm{~g} \mathrm{~L}^{-1}$ $\mathrm{NaH}_{2} \mathrm{PO}_{2}$. Again, diffractograms of coatings indicate that electrodeposited Co-P alloys are amorphous in nature, even it is prepared with small amount of $\mathrm{NaH}_{2} \mathrm{PO}_{2}$.

XRD patterns of Co-P coatings with different $\mathrm{P}$ content heat treated at $400{ }^{\circ} \mathrm{C}$ are displayed in Fig. 2 (b). XRD patterns reveal the amorphous to crystalline transformation of the coatings at these temperatures. The observed diffraction lines for all heat treated coatings match well with hep-Co structure. Since the heat treatment was carried out under $417{ }^{\circ} \mathrm{C}$ (the fcc to hcp phase transformation temperature) there is no allotropic transformation of hcp-Co to fcc-Co is observed in this temperature range. In addition to the hcp-Co peaks, peaks related to $\mathrm{Co}_{2} \mathrm{P}$ phase are also identified in the XRD patterns of the heat treated $\mathrm{Co}-\mathrm{P}$ alloys. The peaks at 40.93 and $52.55^{\circ}$ correspond to $\mathrm{Co}_{2} \mathrm{P}$ phase (JCPDS 32-306), whereas the peaks at 44.29, 47.11, 76.05 and $92.2^{\circ}$ are associated with hcp-Co. ${ }^{9}$ Appearance of $\mathrm{Co}_{2} \mathrm{P}$ phase in heat treated $\mathrm{Co}-\mathrm{P}$ coatings at low $\mathrm{P}$ concentrations in this study is supported by the preceding reports on such types of coatings. ${ }^{20,21}$ However, heat treatment of the coatings at lower temperature also shows the XRD patterns similar to $400{ }^{\circ} \mathrm{C}$.

\subsection{FESEM studies}

The morphology of the as-deposited Co-P coatings characterized by FESEM is displayed in Fig. 3. As-deposited coatings contain rough spherical nodules like cauliflower 
morphology on their surface and surface is free from microcracks. There is no significant effect of different phosphorus contents on the surface morphology of the coatings.

\subsection{AFM studies}

AFM is used to measure the roughness of Co-P coatings. The 3D AFM images of Co-P coatings with 11.6 and 13.7 at.\% P are shown in Fig. 4. Roughness of the coatings is evaluated from $R_{a}$ and $R_{r m s}$ values at time intervals of 5,15 and 30 min of plating. It is distinct from the figure that the surface roughness increases as the plating duration increases. It is very clear from the images that deposits have different surface roughness due to the different growth pattern of the deposit. $R_{a}$ values for 5,15 and $30 \mathrm{~min}$ deposition of coating with 11.6 at.\% P are 280, 600 and $1280 \mathrm{~nm}$, respectively, whereas $R_{\mathrm{rms}}$ values for similar deposition times for this coating are 31, 162 and 284. Roughness characteristics of coatings containing 13.6 and 13.7 at. $\% \mathrm{P}$ are observed to be similar. In the coating with 13.7 at. $\% \mathrm{P}$, observed $\mathrm{R}_{\mathrm{a}}$ values for 5, 15 and 30 min deposition times are 320,980 and $1625 \mathrm{~nm}$, respectively. $\mathrm{R}_{\mathrm{rms}}$ values are found to be 84,228 and $370 \mathrm{~nm}$ in the same coating.

\subsection{DSC studies}

Studies on behavior of amorphous alloy coatings under the effect of heat helps to identify the thermal conditions in which it can be employed. DSC profiles of all $\mathrm{Co}^{-} \mathrm{P}$ alloy coatings with a scan rate of $20^{\circ} \mathrm{C} \mathrm{min}-1$ are displayed in Fig. 5 and the peak temperatures and the respective enthalpies are given in the Table 1. DSC profile of $\mathrm{Co}-\mathrm{P}$ alloy obtained from $2 \mathrm{~g} \mathrm{~L}^{-1} \mathrm{NaH}_{2} \mathrm{PO}_{2}$ contains two exothermic peaks at 280 and $397^{\circ} \mathrm{C}$ which are shifted to 297,392 and $307,384^{\circ} \mathrm{C}$ in Co-P coatings prepared with bath containing 5 and $10 \mathrm{~g} \mathrm{~L}^{-1} \mathrm{NaH}_{2} \mathrm{PO}_{2}$, respectively. A very weak peak at $342{ }^{\circ} \mathrm{C}$ is also noticed in the 
profile of Co-P alloy obtained from $2 \mathrm{~g} \mathrm{~L}^{-1} \mathrm{NaH}_{2} \mathrm{PO}_{2}$ that becomes much more intense when amounts of $\mathrm{NaH}_{2} \mathrm{PO}_{2}$ increase to 5 and $10 \mathrm{~g} \mathrm{~L}^{-1}$. Cebollada et al. showed that the electrodeposited hypoeutectic Co-P coatings with $\mathrm{P}$ content greater than 21 at.\% manifested a single crystallization peak, while those with less than 21 at.\% P crystallize in two consecutive steps that are not fully resolvable. ${ }^{22}$ In the present study, the gradual increase in intensity of the peak at $\sim 342{ }^{\circ} \mathrm{C}$ in relation to other two peaks and the two extreme peaks approaching each other at high P content with decrease in their intensities clearly shows that it approaches the single crystallization peak with the increase in $\mathrm{P}$ content. When the enthalpy values corresponding to peak at $\sim 342{ }^{\circ} \mathrm{C}$ are put into scrutiny, it has been found that there is a drastic increase in the values obtained from the coatings at 5 and $10 \mathrm{~g} \mathrm{~L}^{-1} \mathrm{NaH}_{2} \mathrm{PO}_{2}$ (see Table 1). In addition, a profound decrease in the $\Delta \mathrm{H}$ values of the peak around $390{ }^{\circ} \mathrm{C}$ is noticed which allows us to strongly state that the increase in $\mathrm{P}$ content have a propensity towards displaying a peak for single crystallization for the $\mathrm{Co}-\mathrm{P}$ coatings obtained in this work. Although increase in $\mathrm{P}$ content is not appreciable in the coatings, it is apparent that even the small increase in $\mathrm{P}$ helps in attaining the single crystallization peak. DSC profiles also demonstrate that the stability of the coating increases with increase in P content. Here, the released enthalpies $(\Delta \mathrm{H})$ for lower to higher temperature peaks in all alloys are in the range of 36-38, 5-38 and $22-34 \mathrm{~mJ} \mathrm{~g}^{-1}{ }^{\circ} \mathrm{C}^{-1}$, respectively. In this context, it is interesting to compare these results with the one obtained in the case of pulse electrodeposition. ${ }^{17}$ Pulse electrodeposited $\mathrm{Co}-\mathrm{P}$ deposits exhibit the curves similar to the one obtained by Cebelloda et al. ${ }^{22}$ This is not surprising since the composition of pulse plated coatings obtained from 5 and $10 \mathrm{~g} \mathrm{~L}^{-1} \mathrm{NaH}_{2} \mathrm{PO}_{2}$ bath solutions are very close to that studied by 
Cebelloda and coworkers. However, signs of approaching towards single crystallization peak is also found in pulse current deposited $\mathrm{Co}-\mathrm{P}$ coatings but with slightly higher $\mathrm{P}$ content. ${ }^{17}$ From the DSC studies it is clear that pulse current and direct current deposited coatings have different thermal behaviors due to the difference in phosphorous content obtained by the two deposition methods.

\subsection{XPS studies}

XPS of Co2p core level region in as-deposited Co-P alloy coating obtained from $10 \mathrm{~g} \mathrm{~L}^{-1}$ $\mathrm{NaH}_{2} \mathrm{PO}_{2}$ is given in Fig. 6 along with the spectra of same coating after 10, 20 and 30 min sputtering. In all cases, $\mathrm{Co}$ is in different oxidation states as evident from Co2p core level spectral envelops. Sets of spin-orbit doublets along with associated satellite (S) peaks could be generated after deconvolution of the spectra. Accordingly, Co2 $\mathrm{p}_{3 / 2,1 / 2}$ peaks at 778.0 and $792.9 \mathrm{eV}$ with spin-orbit separation $\left[\Delta \mathrm{E}_{\mathrm{B}}\left(2 \mathrm{p}_{3 / 2}-2 \mathrm{p}_{1 / 2}\right)\right]$ of $14.9 \mathrm{eV}$ observed in as-deposited coating could be assigned for Co metal. On the other hand, peaks at 781.3 and $797.1 \mathrm{eV}$ with $15.8 \mathrm{eV}$ spin-orbit separation could be ascribed to $\mathrm{Co}^{2+}$ from highly ionic $\mathrm{Co}^{2+}$ type of species present in this kind of coatings. ${ }^{23-25}$ In Fig. 7, typical deconvoluted spectrum of Co2p in 30 min sputtered Co-P alloy coating obtained from $10 \mathrm{~g} \mathrm{~L}^{-1} \mathrm{NaH}_{2} \mathrm{PO}_{2}$ is displayed. As-deposited coating contains mainly oxidized species with small amount of Co metal and metal concentration increases in the subsequent layers after successive $10 \mathrm{~min}$ sputtering. The binding energies, relative intensities and FWHMs of different Co species as observed from Co2p spectra of Co-P

alloy coating prepared with $10 \mathrm{~g} \mathrm{~L}^{-1} \mathrm{NaH}_{2} \mathrm{PO}_{2}$ subjected to intermittent sputtering are summarized in Table 2. 
In Fig. 8 XPS of P2p core level in as-deposited as well as sputtered Co-P coating prepared with $10 \mathrm{~g} \mathrm{~L}^{-1} \mathrm{NaH}_{2} \mathrm{PO}_{2}$ are given. $\mathrm{P} 2 \mathrm{p}$ peak is considered as a single peak due to very small binding energy difference $(0.9 \mathrm{eV})$ between $\mathrm{P} 2 \mathrm{p}_{3 / 2}$ and $\mathrm{P} 2 \mathrm{p}_{1 / 2}$ core levels. XPS of P2p in as-deposited Co-P alloy shows two peaks at 129.7 and $133.7 \mathrm{eV}$. P2p core level binding energy in red phosphorous is $130.65 \mathrm{eV} .{ }^{26}$ Therefore, P2p peak in the Co-P alloy coating is shifted by $-0.95 \mathrm{eV}$ in the lower binding energy side in relation to red phosphorous indicating $\mathrm{P}$ is in a negatively charged state $\left(\mathrm{P}^{\delta-}\right)$ that could be assigned for $\mathrm{P}$ of bulk Co-P alloy coating. Thus, a weak charge transfer from Co to $\mathrm{P}$ takes place in $\mathrm{Co}_{-}-\mathrm{P}$ alloy and as $\mathrm{P}$ accepts electrons, $\mathrm{P}$ species interacting with Co in the alloy coating is negatively charged. Similar type of negative shifts have been observed in $\mathrm{Cr}-\mathrm{P}, \mathrm{Mn}-\mathrm{P}$ and $\mathrm{Ni}-\mathrm{P}$ alloys. ${ }^{27-29}$ Higher binding energy peak at $133.7 \mathrm{eV}$ could be attributed to oxidized $\mathrm{P}$ species in $5+$ oxidation state. ${ }^{2-31}$ Presence of both bulk and oxidized $\mathrm{P}$ species in the as-deposited $\mathrm{Co}^{-} \mathrm{P}$ coating agrees well with the literature of this kind of coating. ${ }^{32}$ Amount of $\mathrm{P}^{5+}$ is more than alloyed $\mathrm{P}$ in as-deposited $\mathrm{Co}-\mathrm{P}$ coating. There is an increase in alloyed $\mathrm{P}$ concentration upon successive sputtering up to $30 \mathrm{~min}$. The binding energies, relative intensities and FWHMs of different P species as observed from P2p spectra of Co-P alloys prepared with $10 \mathrm{~g} \mathrm{~L}^{-1} \mathrm{NaH}_{2} \mathrm{PO}_{2}$ for several stages of sputtering are given in Table 3.

The spectral features of XPS of O1s core level region of as-deposited as well as sputtered Co-P alloy coating obtained from $10 \mathrm{~g} \mathrm{~L}^{-1} \mathrm{NaH}_{2} \mathrm{PO}_{2}$ are observed to be broad. Deconvoluted O1s spectrum of as-deposited as well as sputtered coating is displayed in Fig. 9. Peaks at 530.6 and $534.1 \mathrm{eV}$ in as-deposited coating in Fig. 9 (a) can be assigned for $\mathrm{O}^{2-}$ type of species associated with $\mathrm{Co}^{2+}$ ion and adsorbed $\mathrm{H}_{2} \mathrm{O}$ species, 
respectively. ${ }^{10,33}$ On the other hand, an intense peak located at $532.4 \mathrm{eV}$ can correspond to oxygen associated with $\mathrm{P}^{5+}$. Most probable $\mathrm{P}$ related species for this higher binding energy peak is phosphate $\left(\mathrm{PO}_{4}{ }^{3-}\right){ }^{28,30,34}$ Again, alkalization of the electrolyte occurs at the cathode layer due to hydrogen evolution during electrodeposition leading to the formation of $\mathrm{Co}(\mathrm{OH})_{2}$ species on the alloy coating surface which is evident from Co2p core level spectrum of as-deposited coating. ${ }^{24}$ O1s binding energy value of oxygen attached with $\mathrm{P}$ is close to that of metal hydroxide species with little higher region. ${ }^{10,28,30,33,34}$ So its binding energy can overlap with that of metal hydroxide species. Therefore, formation of both $\mathrm{Co}_{3}\left(\mathrm{PO}_{4}\right)_{2}$ and $\mathrm{Co}(\mathrm{OH})_{2}$ species can be possible on the asdeposited coating surface that augers well with the literature. ${ }^{32}$ There is no significant change in the intensity of the peak at $532.4 \mathrm{eV}$ upon 30 min sputtering seen in Fig. 9 (b). However, intensity of $\mathrm{O} 1 \mathrm{~s}$ peak related to adsorbed $\mathrm{H}_{2} \mathrm{O}$ decreases drastically upon sputtering which is obvious. There is a low intensity peak around $536 \mathrm{eV}$ that could be attributed to NaKLL coming from $\mathrm{NaH}_{2} \mathrm{PO}_{2}$ taken during the electrodeposition of the coating. ${ }^{17,35}$ NaKLL peak continues to be present upon successive sputtering.

Relative surface concentrations of $\mathrm{Co}$ and $\mathrm{P}$ of as-deposited and sputtered $\mathrm{Co}-\mathrm{P}$ alloy coatings have been estimated by the relation: ${ }^{36}$

$$
\frac{C_{C o}}{C_{P}}=\frac{I_{C o} \sigma_{P} \lambda_{P} D_{P}}{I_{P} \sigma_{C o} \lambda_{C o} D_{C o}}
$$

where $\mathrm{C}, \mathrm{I}, \sigma, \lambda$ and $\mathrm{D}$ are the surface concentration, intensity, photoionization crosssection, mean escape depth and analyzer detection efficiency, respectively. Integrated intensities of Co2p and P2p peaks have been taken into account to estimate the concentration, whereas photoionization cross-sections and mean escape depths have been obtained from the literature..$^{37,38}$ The geometric factor is taken as 1 , because the maximum 
intensity in this spectrometer is obtained at $90^{\circ}$. Relative surface concentrations (at.\%) of Co and $\mathrm{P}$ in $\mathrm{Co}-\mathrm{P}$ alloy coatings obtained from 5 and $10 \mathrm{~g} \mathrm{~L}^{-1} \mathrm{NaH}_{2} \mathrm{PO}_{2}$ are summarized in Table 4.

XPS studies demonstrate that $\mathrm{Co}^{2+}$ species in the $\mathrm{Co}-\mathrm{P}$ coatings could be related to oxidized Co such as $\mathrm{CoO}$. Observed lower current efficiencies $(62 \pm 5 \%)$ indicates higher hydrogen evolution reaction during electrodeposition which results in $\mathrm{Co}(\mathrm{OH})_{2}$ formation on the coating surface supported by Co2p core level spectra. Possibility of formation of cobalt phosphate kind of species on the surface could also not be ruled out as oxidized $\mathrm{P}$ in the form of $\mathrm{PO}_{4}{ }^{3-}$ species is present as revealed by $\mathrm{O} 1 \mathrm{~s}$ core level spectra. $\mathrm{P}$ is present as bulk alloy $\left(\mathrm{P}^{\delta-}\right)$ and oxidized $\left(\mathrm{P}^{5+}\right)$ forms in as-deposited coating and bulk alloy continues to dominate up to certain successive layers as revealed by XPS studies. Surface concentrations of Co and P evaluated from XPS demonstrate that Co segregates on the surface of the alloy coatings. Decrease in P concentration in alloy deposits are observed after first sputtering (Table 4) and after that P concentration does not change much indicating that alloy coatings maintain uniform composition up to certain layers.

\subsection{Microhardness studies}

Microhardness measurements of all Co-P alloy deposits were carried out on the surface of as-deposited as well as heat treated coatings and the values are given in Table 5. Asdeposited alloy coatings show hardness values of 465,480 and 485 HK for coatings

obtained from 2, 5 and $10 \mathrm{~g} \mathrm{~L}^{-1} \mathrm{NaH}_{2} \mathrm{PO}_{2}$, respectively. The hardness obtained is higher than electrodeposited Co $(\sim 300 \mathrm{HK}) .{ }^{1}$ The increase in hardness of Co-P coatings is due to the alloying of Co with P and amorphous nature of the deposits. It is important to note 
that microhardness values of as-deposited DC plated Co-P coatings observed in this study are less compared to that of previously studied pulse plated coatings. ${ }^{17}$ In pulse electrodeposition, very high instantaneous current densities are applied and hence more negative potentials can be attained. These negative potentials associated with the high pulse current density also greatly enhances the nucleation rate and other coating characteristics such as density of pores, mechanical and electrical properties. Therefore, comparatively decreased microhardness in as-deposited DC plated coatings could be due to its differences in coating nature from the pulse plated coatings.

Significant increase in microhardness is observed in heat treated Co-P coatings with respect to the as-deposited coatings. Hardness values of 890, 995 and $1005 \mathrm{HK}$ are obtained in all coatings heat treated with at $400{ }^{\circ} \mathrm{C}$ where coating prepared with $10 \mathrm{~g} \mathrm{~L}^{-1}$ $\mathrm{NaH}_{2} \mathrm{PO}_{2}$ shows highest hardness value. We also observe an increasing trend in the hardness values of the Co-P coatings (Table 5) with increase in $\mathrm{P}$ concentration at heat treatment temperature of $\sim 300^{\circ} \mathrm{C}$. Heat treatment of the coating obtained from $10 \mathrm{~g} \mathrm{~L}^{-1}$ $\mathrm{NaH}_{2} \mathrm{PO}_{2}$ at $300{ }^{\circ} \mathrm{C}$ results in hardness value of $855 \mathrm{HK}$. Within this context, increasing trend in hardness in heat treated Co-P coatings is contrary to the behavior of heat treated hard chromium coatings. It was well established that hard chromium coatings exhibited very high hardness values of $\sim 1000 \mathrm{HV},{ }^{39,40}$ but hardness values decreased drastically upon heat treatment. ${ }^{40}$ Hardness of conventional chromium coating decreased to 810 , $585,270,100 \mathrm{HV}$ when it was heated at $200,400,600$ and $800{ }^{\circ} \mathrm{C}$, respectively. ${ }^{39}$ In the present study, microhardness value of $485 \mathrm{HK}$ in as-deposited Co-P coating prepared with $10 \mathrm{~g} \mathrm{~L}^{-1} \mathrm{NaH}_{2} \mathrm{PO}_{2}$ bath increases to $1005 \mathrm{HK}$ when it is heat treated. Hardness values measured in heat treated $\mathrm{Co}-\mathrm{P}$ coatings studied here could be comparable with as- 
deposited conventional hard chromium coatings. The increase in hardness in heat treated Co-P alloy coatings has mainly been ascribed to the formation of crystalline phase and also to the development of $\mathrm{Co}_{2} \mathrm{P}$ phase demonstrated by XRD studies during the heat treatment. Even though increase in phosphorous content is one of the reasons for the increase in hardness, the other probable basis would be the change in the DSC peaks to a single crystallization one with the increase in P content. It is strongly believed that the approach to the single crystallization peak has strong impact in the enhancement of the microhardness values in the heat treated condition.

\section{Conclusions}

In the present study, $\mathrm{Co}_{-} \mathrm{P}$ alloy coatings are electrodeposited using direct current and gluconate bath. As-deposited $\mathrm{Co}-\mathrm{P}$ coatings are amorphous in nature as demonstrated by XRD. Heat treated coatings contain $\mathrm{Co}_{2} \mathrm{P}$ phase along with hcp-Co. DSC profiles show three exothermic peaks in all $\mathrm{Co}^{-} \mathrm{P}$ coatings and also demonstrate the approaching to the single crystallization peak with increase in $\mathrm{P}$ content. All Co-P alloy deposits exhibit rough spherical bright nodules with good uniformity. XPS studies show that as-deposited alloy coatings consist mainly of $\mathrm{Co}^{2+}$ species along with $\mathrm{Co}$ metal, whereas $\mathrm{P}$ binding energies could be assigned for $\mathrm{P}^{\delta-}$ and $\mathrm{P}^{5+}$ forms. Amounts of Co metal increase with successive sputtering of the alloy. On the other hand, reduction of oxidized P can be observed upon mild sputtering in case of the coating obtained from $10 \mathrm{~g} \mathrm{~L}^{-1} \mathrm{NaH}_{2} \mathrm{PO}_{2}$. Surface concentrations evaluated from XPS analysis indicate that Co is segregated over the alloy surface and $\mathrm{P}$ concentration decreases slightly upon sputtering and after that it maintains same concentration. Heat treated Co-P coatings show comparable hardness to conventional hard chromium. 


\section{Acknowledgments}

Authors would like to thank the Director, CSIR-National Aerospace Laboratories for giving permission to publish this work. Authors wish to acknowledge the help rendered by Mr. Siju, Mr. Manikandanath and Mr. Praveen for carrying out FESEM, DSC and microhardness measurements, respectively. Authors are thankful to Prof. M. S. Hegde

and Dr. C. Shivakumara, Indian Institute of Science, Bangalore for providing XPS and XRD facilities, respectively.

\section{References}

1. S. Eskin, O. Berkh, G. Rogalsky and J. Zahavi, Plat. Surf. Finish. 85(4) (1998) 79.

2. D. P. Weston, P. H. Shipway, S. J. Harris and M. K. Cheng, Wear 267 (2009) 934.

3. J. H. Lindsay, Plat. Surf. Finish. 82(2) (1995) 19.

4. F. Su and P. Huang, Mater. Chem. Phys. 134 (2012) 350.

5. R. A. Prado and D. Facchini, DoD Corrosion Conference, 2009.

6. K. Rymer and A. Przywóski, 9th Youth Symposium on Experimental Solid Mechanics, Trieste, Italy, July 7-10, 2010, p. 112.

7. M. A. Sheikholeslam, M. H. Enayati and K. Raeissi, Mater. Lett. 62 (2008) 3629.

8. J. McCrea, S. Kim, D. Jeong, F. Gonzalez and G. Palumbo, Proc. AESF SUR/FIN: 2005, Saint Louis, American Electroplaters and Surface Finishers, 2005, p. 1.

9. H. Jung and A. Alfantazi, Electrochim. Acta 51 (2006) 1806.

10. H. Jung and A. Alfantazi, Corrosion 63 (2007) 159.

11. M. A. Helfand, C. R. Clayton, R. B. Diegle and N. R. Sorenson, J. Electrochem. Soc. 139 (1992) 2121. 
12. N. Petrov, Y. Sverdlov and Y. Shacham-Diamand, J. Electrochem. Soc. 149 (2002) C187.

13. L. P. Bicelli, B. Bozzini, C. Mele and L. D'Urzo, Int. J. Electrochem. Sci. 3 (2008) 356.

14. I. Gurrappa and L. Binder, Sci. Technol. Adv. Mater. 9 (2008) 043001.

15. A. Brenner, C. Chase, D. E. Couch, H. Md and K. Eugenia, US patent 2643221, 1953.

16. D. P. Weston, S. J. Harris, P. H. Shipway, N. J. Weston, G. N. Yap, Electrochim. Acta 55 (2010) 5695.

17. P. Bera, H. Seenivasan, K. S. Rajam and V. K. W. Grips, Appl. Surf. Sci. 258 (2012) 9544.

18. D. Briggs and M. P. Seah, Practical Surface Analysis by Auger and X-ray Photoelectron Spectroscopy, Wiley, New York, 1984.

19. C. S. Lin, C. Y. Lee, F. J. Chen, C. T. Chein, P. L. Lin and W. C. Chung, J. Electrochem. Soc. 153 (2006) C387.

20. H. J. Yun, S. M. S. I. Dulal, C. B. Shin and C.-K. Kim, Electrochim. Acta 54 (2008) 370.

21. A. Kohn, M. Eizenberg, Y. Shacham-Diamand and Y. Sverdlov, Mater. Sci. Eng. A $302(2001) 18$.

22. F. Cebollada, J. M. González, C. de Julián and S. Suriñach, Phys. Rev. B 56 (1997) 6056.

23. W.-L. Dai, M.-H. Qiao and J.-F. Deng, Appl. Surf. Sci. 120 (1997) 119. 
24. L. Orlovskaja, E. Matulionis, A. Timinskas and V. Šukienè, Surf. Coat. Technol. 135 (2000) 34 .

25. S. M. S. I. Dulal, H. J. Yun, C. B. Shin and C.-K. Kim, Electrochim. Acta 53 (2007) 934.

26. R. Franke, T. Chassé, P. Streubel and A. Meisel, J. Electron Spectrosc. Relat. Phenom. 56 (1991) 381.

27. M. Pelavin, D. N. Hendrickson, J. M. Hollander and W. L. Jolly, J. Phys. Chem. 74 (1970) 1116.

28. K. S. Rajam, S. R. Rajagopalan, M. S. Hegde and B. Viswanathan, Mater. Chem. Phys. 27 (1991) 141.

29. B. Elsener, M. Crobu, M. A. Scorciapino and A. Rossi, J. Appl. Electrochem. 38 (2008) 1053.

30. C. L. Aravinda, P. Bera, V. Jayaram and S. M. Mayanna, Appl. Surf. Sci. 191 (2002) 128.

31. D. Barreca, A. Camporese, M. Casarin, N. El Habra, A. Gasparotto, M. Natali, G. Rossetto, E. Tondello and P. Zanella, J. Electrochem. Soc. 151 (2004) G638.

32. K. Shimizu, K. Kobayashi, P. Skeldon, G. E. Thompson and G. C. Wood, Mater. Sci. Eng. A 198 (1995) 35.

33. T. Choudhury, S. O. Saied, J. L. Sullivan and A. M. Abbot, J. Phys. D: Appl. Phys. $22(1989) 1185$.

34. T. Chassé, R. Franke, C. Urban, R. Franzheld, P. Streubel and A. Meisel, J. Electron Spectrosc. Relat. Phenom. 62 (1993) 287.

35. A. Mekki, D. Holland and C. F. McConville, J. Non-Cryst. Solids 215 (1997) 271. 
36. C. J. Powell and P. E. Larson, Appl. Surf. Sci. 1 (1978) 186.

37. J. H. Scofield, J. Electron Spectrosc. Relat. Phenom. 8 (1976) 129.

38. D. R. Penn, J. Electron Spectrosc. Relat. Phenom. 9 (1976) 29.

39. W. Hume-Rothery and M. R. J. Wyllie, Proc. Royal Soc. London A 181 (1943) 331.

40. Wear resistant surfaces in engineering-a guide to their production, properties and selection, International Research and Development Co Ltd, London, 1986, p. 85. 
Table 1. Peak temperatures $\left({ }^{\circ} \mathrm{C}\right)$ and $\Delta \mathrm{H}$ values $\left(\mathrm{mJ} \mathrm{g}^{-1}{ }^{\circ} \mathrm{C}^{-1}\right)$ obtained from DSC thermograms of DC electrodeposited Co-P coatings with scan rate of $20^{\circ} \mathrm{C} \mathrm{min}^{-1}$

\begin{tabular}{|c|c|c|c|}
\hline Coatings & $\begin{array}{c}\text { Peak1 } \\
(\Delta \mathrm{H} 1)\end{array}$ & $\begin{array}{c}\text { Peak2 } \\
(\Delta \mathrm{H} 2)\end{array}$ & $(\Delta \mathrm{H} 3)$ \\
\hline $\mathrm{Co}-\mathrm{P}$ & 279.52 & 341.83 & $(-34.35)$ \\
\hline$\left(2 \mathrm{~g} \mathrm{~L}^{-1} \mathrm{NaH}_{2} \mathrm{PO}_{2}\right)$ & $(-36.82)$ & $(-4.97)$ & 392.25 \\
\hline $\mathrm{Co}^{-\mathrm{P}}$ & 297.25 & 342.89 & $(-31.28)$ \\
\hline$\left(5 \mathrm{~g} \mathrm{~L}^{-1} \mathrm{NaH}_{2} \mathrm{PO}_{2}\right)$ & $(-38.02)$ & $(-13.45)$ & 384.23 \\
\hline $\mathrm{Co}^{-\mathrm{P}}$ & 306.58 & 343.24 & $(-22.72)$ \\
\hline
\end{tabular}


Table 2. Binding energies, relative intensities and FWHMs of different Co species as observed from Co2p of as-deposited and sputtered Co-P alloy prepared with $10 \mathrm{~g} \mathrm{~L}^{-1}$ $\mathrm{NaH}_{2} \mathrm{PO}_{2}$

\begin{tabular}{|c|c|c|c|c|c|c|}
\hline $\begin{array}{l}\text { Duration of } \\
\text { sputtering (min) }\end{array}$ & $\begin{array}{l}\text { Co } \\
\text { species }\end{array}$ & $\begin{array}{l}\mathrm{E}_{\mathrm{B}} \text { of } \\
\mathrm{Co} 2 \mathrm{p}_{3 / 2} \\
(\mathrm{eV})\end{array}$ & $\begin{array}{l}\text { Relative } \\
\text { intensity } \\
(\%)\end{array}$ & $\begin{array}{l}\text { FWHM of } \\
\mathrm{Co} 2 \mathrm{p}_{3 / 2} \\
(\mathrm{eV})\end{array}$ & $\begin{array}{l}\Delta E_{B}\left(2 p_{3 / 2}-2 p_{1 / 2}\right) \\
(e V)\end{array}$ & $\begin{array}{l}\Delta \mathrm{E}_{\mathrm{B}}\left(2 \mathrm{p}_{3 / 2}-\mathrm{S}\right) \\
(\mathrm{eV})\end{array}$ \\
\hline As-deposited & $\begin{array}{l}\mathrm{Co}^{0} \\
\mathrm{Co}^{2+}\end{array}$ & $\begin{array}{l}778.0 \\
781.3\end{array}$ & $\begin{array}{l}18 \\
82\end{array}$ & $\begin{array}{l}2.15 \\
3.12\end{array}$ & $\begin{array}{l}14.9 \\
15.8\end{array}$ & $\begin{array}{l}- \\
4.0\end{array}$ \\
\hline 10 & $\begin{array}{l}\mathrm{Co}^{0} \\
\mathrm{Co}^{2+}\end{array}$ & $\begin{array}{l}778.1 \\
781.4\end{array}$ & $\begin{array}{l}48 \\
52\end{array}$ & $\begin{array}{l}2.05 \\
4.05\end{array}$ & $\begin{array}{l}15.0 \\
15.8\end{array}$ & $\begin{array}{l}- \\
4.8\end{array}$ \\
\hline 20 & $\begin{array}{l}\mathrm{Co}^{0} \\
\mathrm{Co}^{2+}\end{array}$ & $\begin{array}{l}778.2 \\
781.2\end{array}$ & $\begin{array}{l}64 \\
36\end{array}$ & $\begin{array}{l}1.82 \\
4.92\end{array}$ & $\begin{array}{l}15.0 \\
15.7\end{array}$ & $\begin{array}{l}- \\
4.5\end{array}$ \\
\hline 30 & $\begin{array}{l}\mathrm{Co}^{0} \\
\mathrm{Co}^{2+}\end{array}$ & $\begin{array}{l}778.2 \\
781.2\end{array}$ & $\begin{array}{l}67 \\
33\end{array}$ & $\begin{array}{l}1.95 \\
4.62\end{array}$ & $\begin{array}{l}15.0 \\
15.8\end{array}$ & $\begin{array}{l}- \\
4.8\end{array}$ \\
\hline
\end{tabular}


Table 3. Binding energies, relative intensities and FWHMs of different $\mathrm{P}$ species as observed from P2p of as-deposited and sputtered Co-P alloy prepared with $10 \mathrm{~g} \mathrm{~L}^{-1}$ $\mathrm{NaH}_{2} \mathrm{PO}_{2}$

\begin{tabular}{|c|c|c|c|c|}
\hline $\begin{array}{l}\text { Duration of } \\
\text { sputtering (min) }\end{array}$ & P species & $E_{B}$ of $P 2 p(e V)$ & $\begin{array}{l}\text { Relative } \\
\text { intensity (\%) }\end{array}$ & $\begin{array}{l}\text { FWHM of } \\
\text { P2p (eV) }\end{array}$ \\
\hline As-deposited & $\begin{array}{l}\mathrm{P}^{\delta-} \\
\mathrm{P}^{5+}\end{array}$ & $\begin{array}{l}129.7 \\
133.7\end{array}$ & $\begin{array}{l}39 \\
61\end{array}$ & $\begin{array}{l}2.05 \\
2.19\end{array}$ \\
\hline 10 & $\begin{array}{l}\mathrm{P}^{\delta-} \\
\mathrm{P}^{5+}\end{array}$ & $\begin{array}{l}129.8 \\
133.7\end{array}$ & $\begin{array}{l}48 \\
52\end{array}$ & $\begin{array}{l}2.12 \\
2.25\end{array}$ \\
\hline 20 & $\begin{array}{l}\mathrm{P}^{\delta-} \\
\mathrm{P}^{5+}\end{array}$ & $\begin{array}{l}129.7 \\
133.5\end{array}$ & $\begin{array}{l}56 \\
44\end{array}$ & $\begin{array}{l}2.07 \\
2.36\end{array}$ \\
\hline 30 & $\begin{array}{l}\mathrm{P}^{\delta-} \\
\mathrm{P}^{5+}\end{array}$ & $\begin{array}{l}129.7 \\
133.6\end{array}$ & $\begin{array}{l}65 \\
35\end{array}$ & $\begin{array}{l}2.17 \\
2.47\end{array}$ \\
\hline
\end{tabular}


Table 4. Relative surface composition of Co-P alloy coatings DC electrodeposited with 5 and $10 \mathrm{~g} \mathrm{~L}^{-1} \mathrm{NaH}_{2} \mathrm{PO}_{2}$ at different stages of sputtering as obtained from XPS analysis

\begin{tabular}{|c|c|c|c|c|}
\hline \multirow{2}{*}{$\begin{array}{c}\text { Duration of } \\
\text { sputtering (min) }\end{array}$} & \multicolumn{2}{|c|}{$5 \mathrm{~g} \mathrm{~L}^{-1} \mathrm{NaH}_{2} \mathrm{PO}_{2}$} & \multicolumn{2}{c|}{$10 \mathrm{~g} \mathrm{~L}^{-1} \mathrm{NaH}_{2} \mathrm{PO}_{2}$} \\
\cline { 2 - 5 } & $\mathrm{Co}$ (at.\%) & $\mathrm{P}$ (at.\%) & $\mathrm{Co}$ (at.\%) & $\mathrm{P}$ (at.\%) \\
\hline As-deposited & 74 & 26 & 70 & 30 \\
\hline 10 & 71 & 29 & 75 & 25 \\
\hline 20 & 80 & 20 & 81 & 19 \\
\hline 30 & 78 & 22 & 81 & 19 \\
\hline
\end{tabular}


Table 5. Microhardness of the as-deposited and heat treated $\mathrm{Co}-\mathrm{P}$ coatings

\begin{tabular}{|c|c|c|}
\hline \multirow{2}{*}{ Coatings } & \multicolumn{2}{|c|}{ Microhardness (HK) } \\
\cline { 2 - 3 } & \multicolumn{1}{|c|}{ As-deposited } & Heat treated \\
\hline $\mathrm{Co}-\mathrm{P}$ & $465 \pm 20$ & $890 \pm 20\left(280^{\circ} \mathrm{C}\right)$ \\
$\left(2 \mathrm{~g} \mathrm{~L}^{-1} \mathrm{NaH}_{2} \mathrm{PO}_{2}\right)$ & & $760 \pm 20\left(300^{\circ} \mathrm{C}\right)$ \\
\hline $\mathrm{Co}^{-\mathrm{P}}$ & $480 \pm 20$ & $995 \pm 20\left(400^{\circ} \mathrm{C}\right)$ \\
\hline$\left(5 \mathrm{~g} \mathrm{~L}^{-1} \mathrm{NaH}_{2} \mathrm{PO}_{2}\right)$ & & $855 \pm 20\left(300^{\circ} \mathrm{C}\right)$ \\
\hline $\mathrm{Co}^{\circ} \mathrm{P}$ & $485 \pm 20$ & $1005 \pm 20\left(400^{\circ} \mathrm{C}\right)$ \\
\hline
\end{tabular}




\section{Figure captions}

Fig. 1. EDXS of as-deposited Co-P alloy coatings prepared with (a) 2, (b) 5 and (c) $10 \mathrm{~g}$ $\mathrm{L}^{-1} \mathrm{NaH}_{2} \mathrm{PO}_{2}$ containing $11.6,13.6$ and 13.7 at.\% $\mathrm{P}$, respectively.

Fig. 2. XRD of as-deposited (top) and heat treated at $400{ }^{\circ} \mathrm{C}$ (bottom) $\mathrm{Co}-\mathrm{P}$ alloy coatings prepared with (a) 2, (b) 5 and (c) $10 \mathrm{~g} \mathrm{~L}^{-1} \mathrm{NaH}_{2} \mathrm{PO}_{2}$ containing 11.6, 13.6 and 13.7 at. $\% \mathrm{P}$, respectively.

Fig. 3. FESEM images of as-deposited Co-P alloy coatings prepared with (a) 2, (b) 5 and (c) $10 \mathrm{~g} \mathrm{~L}^{-1} \mathrm{NaH}_{2} \mathrm{PO}_{2}$ containing $11.6,13.6$ and 13.7 at.\% $\mathrm{P}$, respectively.

Fig. 4. AFM images of as-deposited Co-P alloy coatings prepared with (a) 2 and (b) $10 \mathrm{~g}$ $\mathrm{L}^{-1} \mathrm{NaH}_{2} \mathrm{PO}_{2}$ containing 11.6 and 13.7 at.\% $\mathrm{P}$, respectively.

Fig. 5. DSC profiles of as-deposited Co-P alloy coatings prepared with (a) 2, (b) 5 and

(c) $10 \mathrm{~g} \mathrm{~L}^{-1} \mathrm{NaH}_{2} \mathrm{PO}_{2}$ containing $11.6,13.6$ and 13.7 at.\% $\mathrm{P}$, respectively.

Fig. 6. XPS of core level Co2p of Co-P alloy coating obtained from $10 \mathrm{~g} \mathrm{~L}^{-1} \mathrm{NaH}_{2} \mathrm{PO}_{2}$ (13.7 at.\% P) at different stages of sputtering: (a) as-deposited, (b) after 10 min sputtering, (c) after 20 min sputtering and (d) after 30 min sputtering.

Fig. 7. Deconvoluted XPS of Co2p in Co-P alloy coating obtained from $10 \mathrm{~g} \mathrm{~L}^{-1}$ $\mathrm{NaH}_{2} \mathrm{PO}_{2}(13.7$ at.\% $\mathrm{P})$ after 30 min sputtering.

Fig. 8. XPS of core level $\mathrm{P} 2 \mathrm{p}$ of $\mathrm{Co}-\mathrm{P}$ alloy coating obtained from $10 \mathrm{~g} \mathrm{~L}^{-1} \mathrm{NaH}_{2} \mathrm{PO}_{2}$ (13.7 at.\% P) at different stages of sputtering: (a) as-deposited, (b) after 10 min sputtering, (c) after 20 min sputtering and (d) after 30 min sputtering.

Fig. 9. XPS of core level O1s of Co-P alloy coating obtained from $10 \mathrm{~g} \mathrm{~L}^{-1} \mathrm{NaH}_{2} \mathrm{PO}_{2}$ (13.7 at.\% P): (a) as-deposited and (b) after 30 min sputtering. 

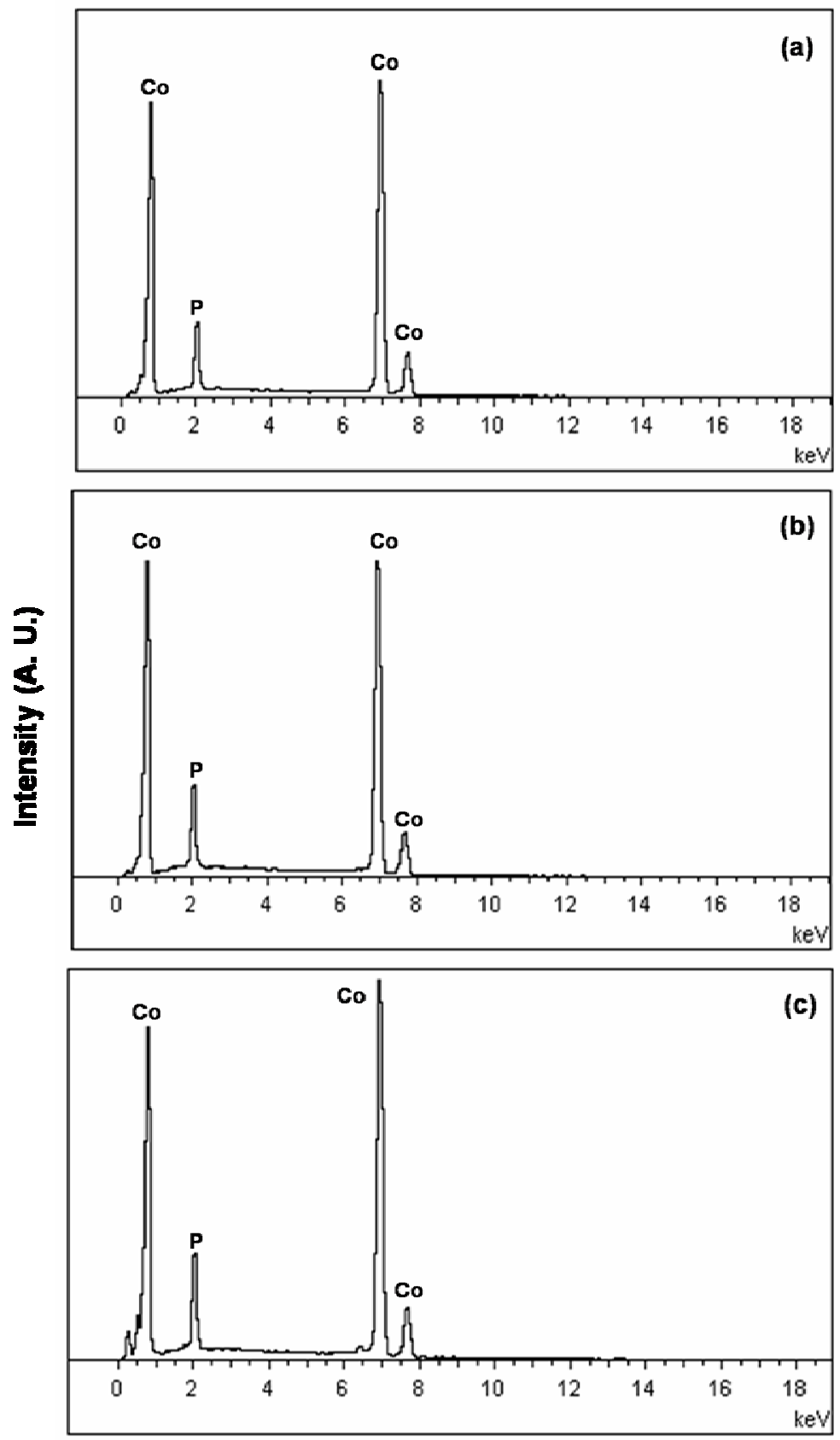

Fig. 1. EDXS of as-deposited Co-P alloy coatings prepared with (a) 2, (b) 5 and (c) 105 $\mathrm{g} \mathrm{L}^{-1} \mathrm{NaH}_{2} \mathrm{PO}_{2}$ containing $11.6,13.6$ and 13.7 at.\% $\mathrm{P}$, respectively. 

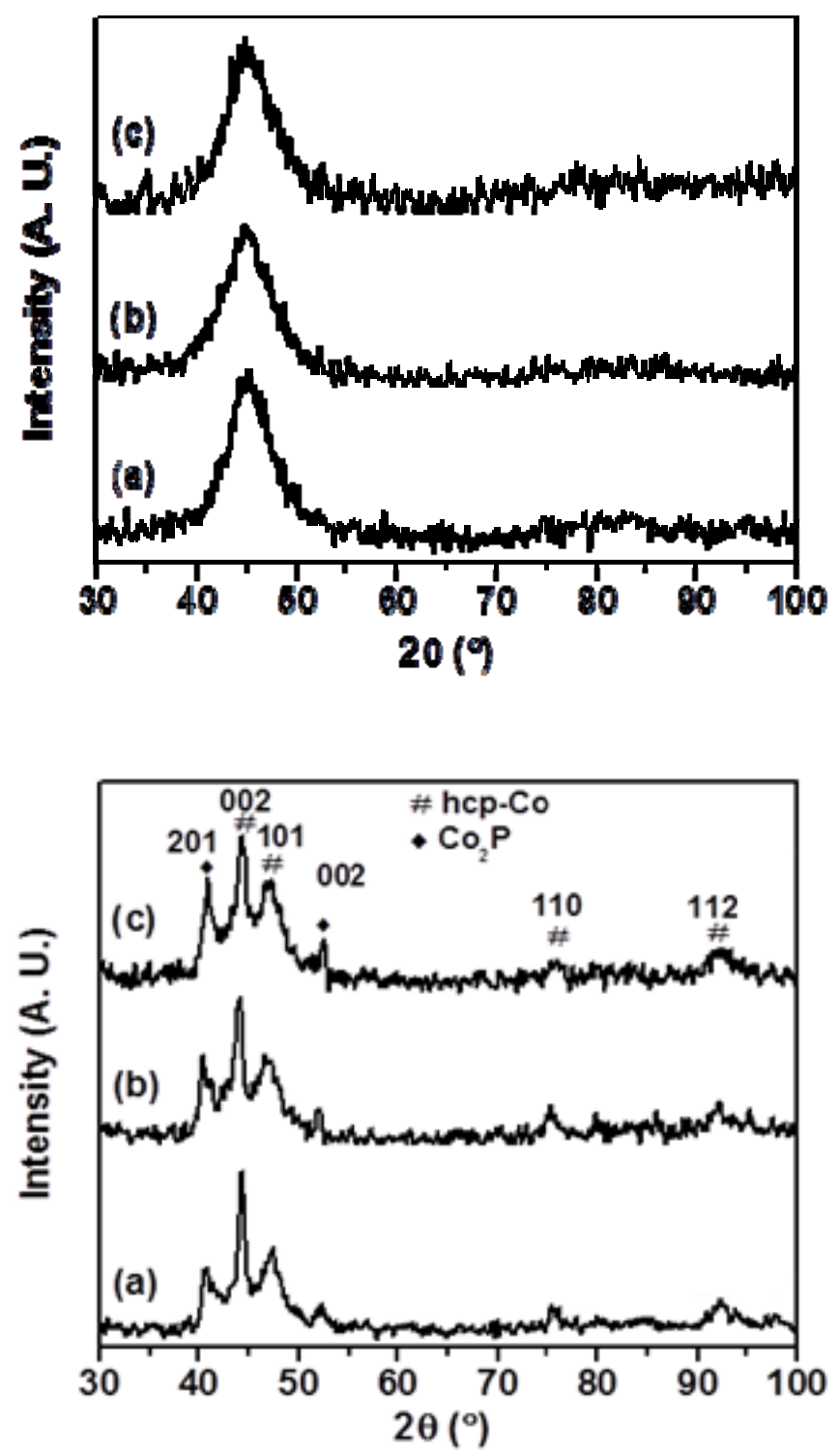

Fig. 2. XRD of as-deposited (top) and heat treated at $400{ }^{\circ} \mathrm{C}$ (bottom) $\mathrm{Co}-\mathrm{P}$ alloy coatings prepared with (a) 2, (b) 5 and (c) $10 \mathrm{~g} \mathrm{~L}^{-1} \mathrm{NaH}_{2} \mathrm{PO}_{2}$ containing 11.6, 13.6 and 13.7 at. $\%$ P, respectively. 

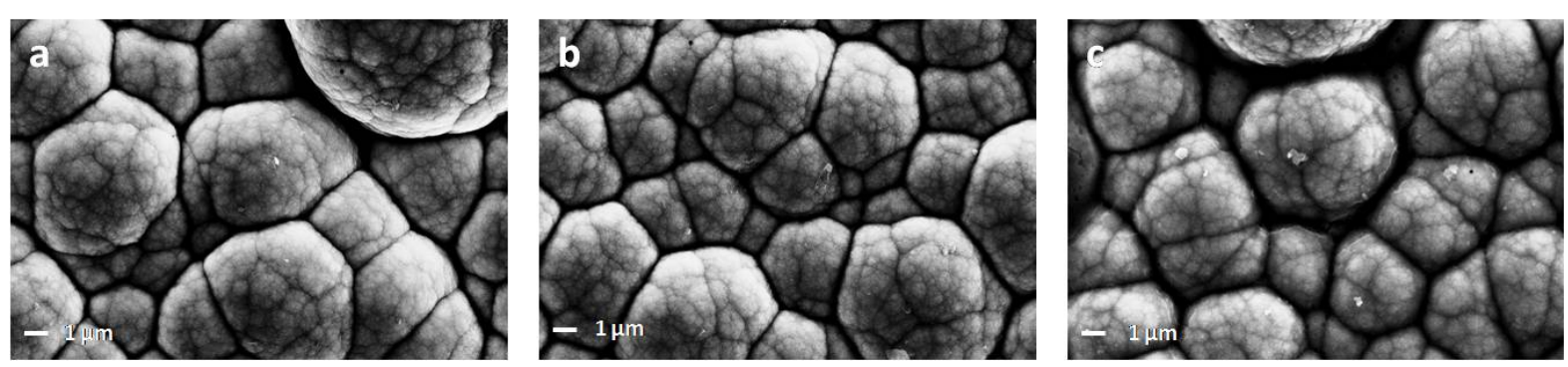

Fig. 3. FESEM images of as-deposited Co-P alloy coatings prepared with (a) 2, (b) 5 and (c) $10 \mathrm{~g} \mathrm{~L}^{-1} \mathrm{NaH}_{2} \mathrm{PO}_{2}$ containing 11.6, 13.6 and 13.7 at.\% $\mathrm{P}$, respectively. 

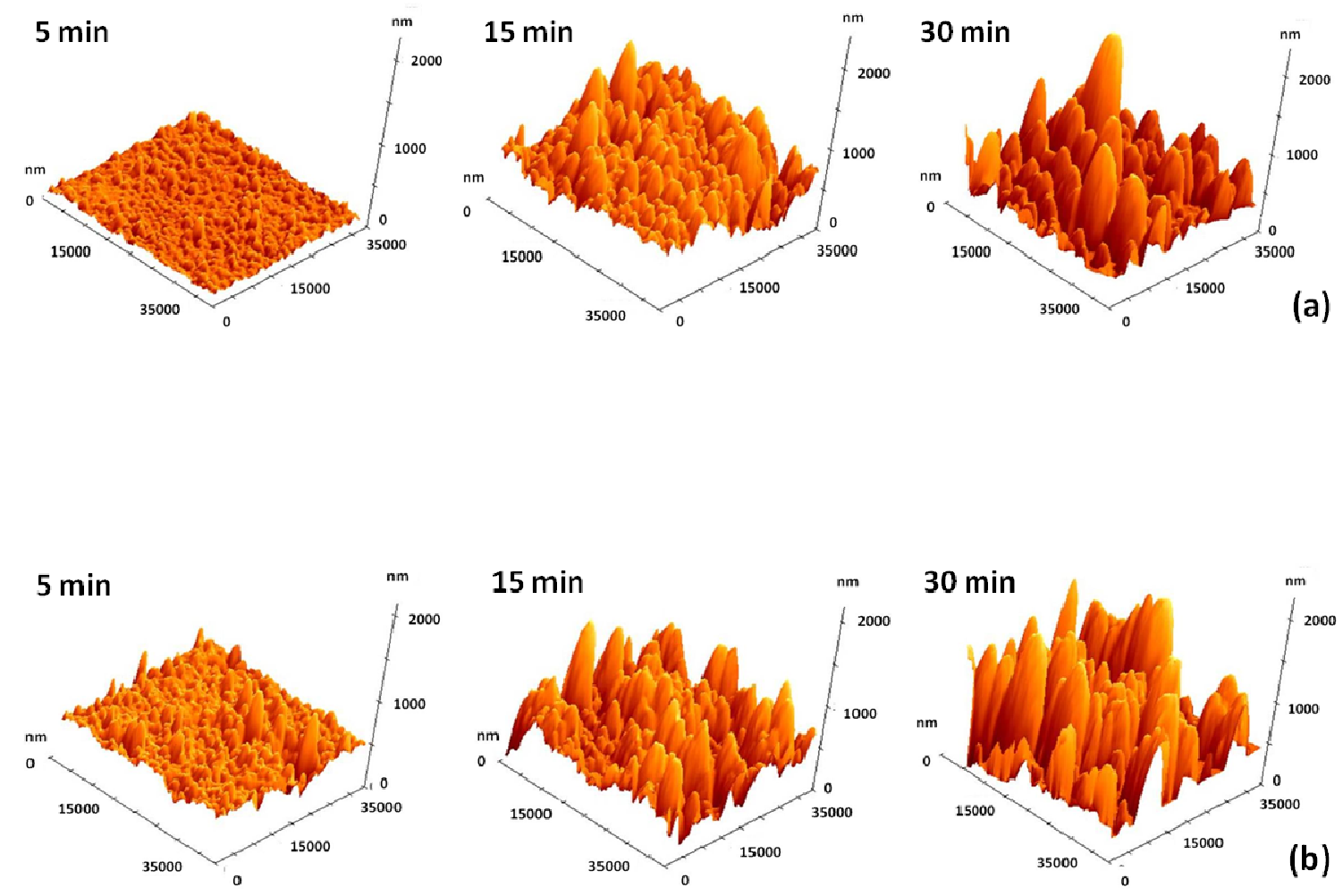

Fig. 4. AFM images of as-deposited Co-P alloy coatings prepared with (a) 2 and (b) $10 \mathrm{~g}$ $\mathrm{L}^{-1} \mathrm{NaH}_{2} \mathrm{PO}_{2}$ containing 11.6 and 13.7 at. $\% \mathrm{P}$, respectively. 


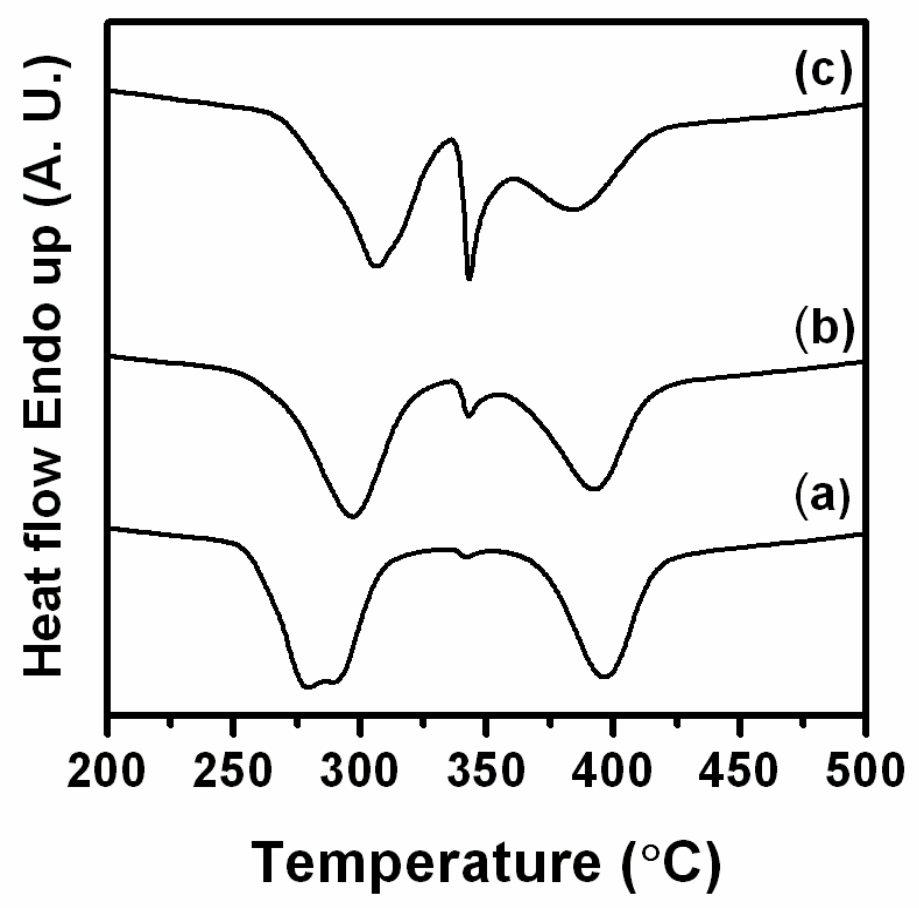

Fig. 5. DSC profiles of as-deposited Co-P alloy coatings prepared with (a) 2, (b) 5 and (c) $10 \mathrm{~g} \mathrm{~L}^{-1} \mathrm{NaH}_{2} \mathrm{PO}_{2}$ containing 11.6, 13.6 and 13.7 at.\% $\mathrm{P}$, respectively. 


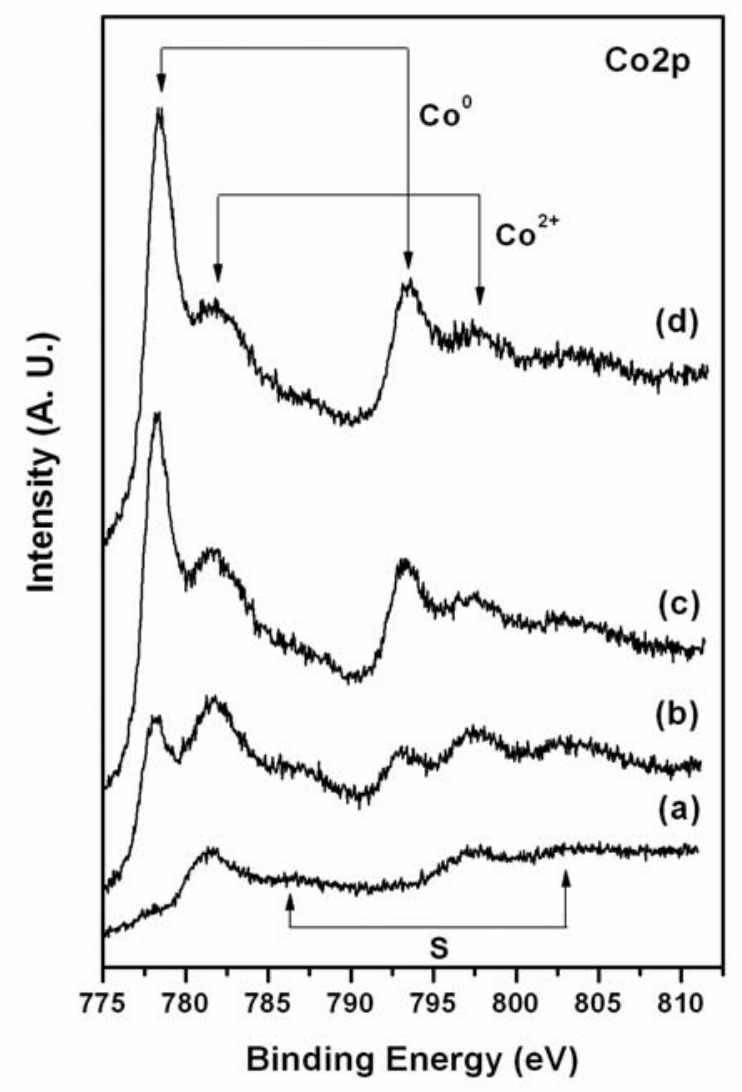

Fig. 6. XPS of core level Co2p of Co-P alloy coating obtained from $10 \mathrm{~g} \mathrm{~L}^{-1} \mathrm{NaH}_{2} \mathrm{PO}_{2}$ (13.7 at.\% P) at different stages of sputtering: (a) as-deposited, (b) after $10 \mathrm{~min}$ sputtering, (c) after 20 min sputtering and (d) after 30 min sputtering. 


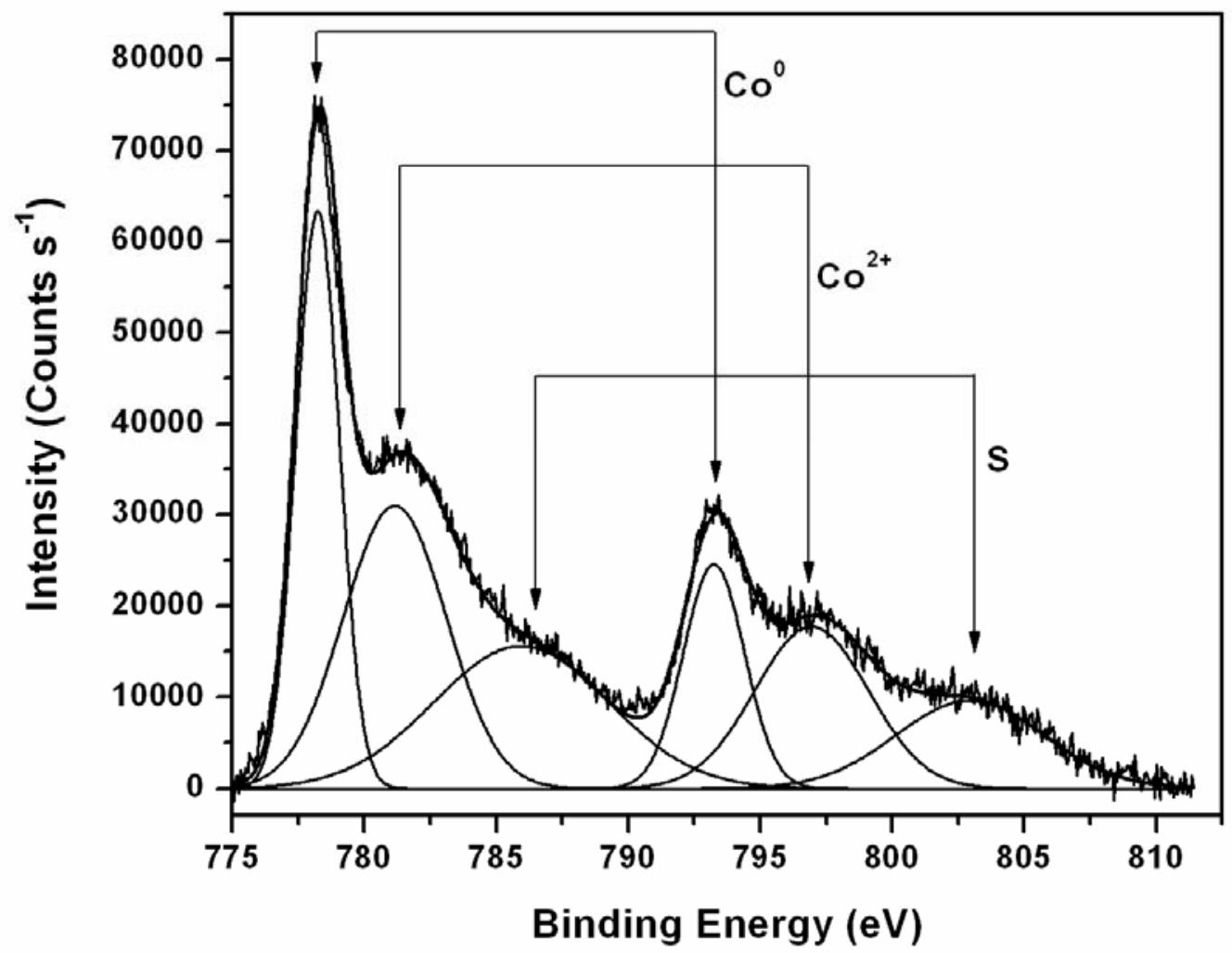

Fig. 7. Deconvoluted XPS of Co2p in Co-P alloy coating obtained from $10 \mathrm{~g} \mathrm{~L}^{-1}$ $\mathrm{NaH}_{2} \mathrm{PO}_{2}(13.7$ at.\% $\mathrm{P})$ after 30 min sputtering. 


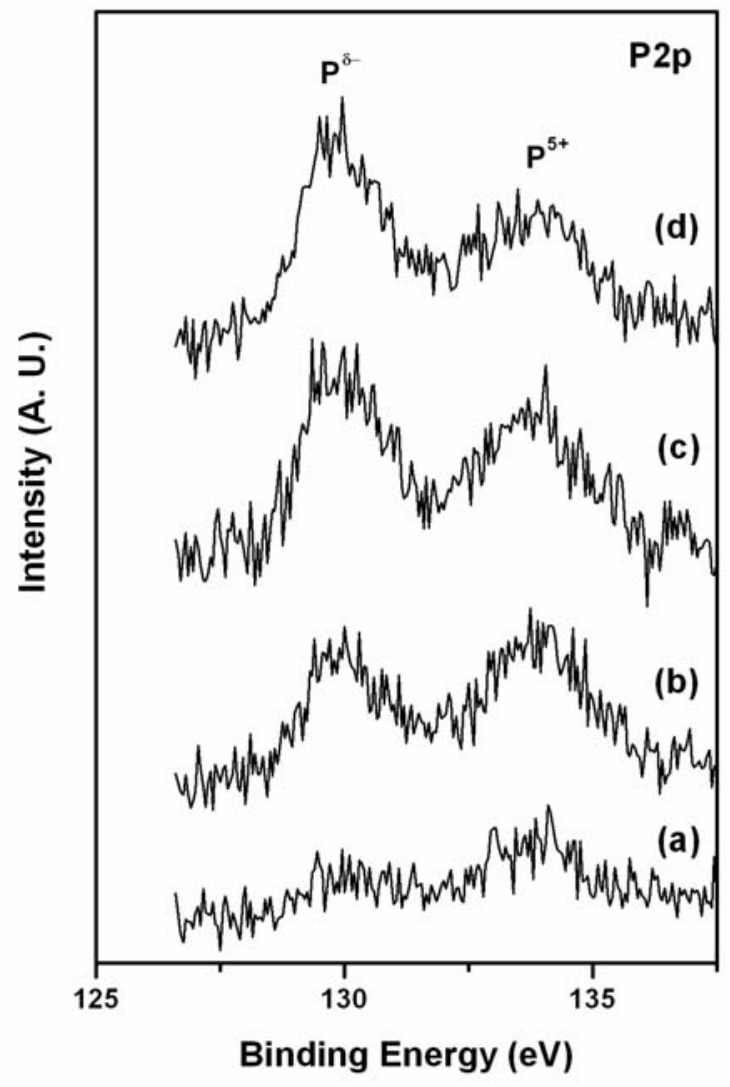

Fig. 8. XPS of core level P2p of Co-P alloy coating obtained from $10 \mathrm{~g} \mathrm{~L}^{-1} \mathrm{NaH}_{2} \mathrm{PO}_{2}$ (13.7 at.\% P) at different stages of sputtering: (a) as-deposited, (b) after $10 \mathrm{~min}$ sputtering, (c) after 20 min sputtering and (d) after 30 min sputtering. 

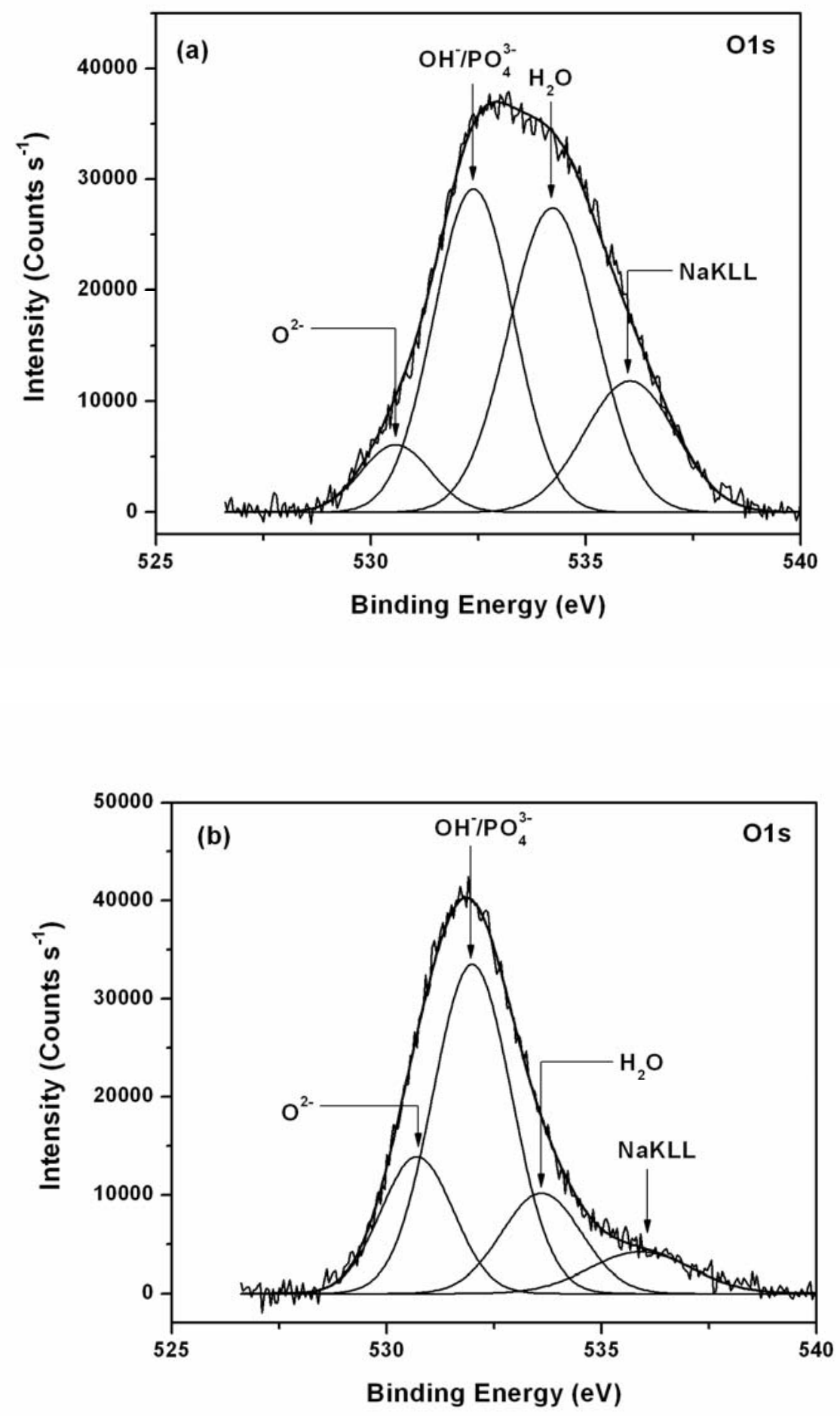

Fig. 9. Deconvoluted XPS of core level O1s of Co-P alloy coating obtained from $10 \mathrm{~g}$ $\mathrm{L}^{-1} \mathrm{NaH}_{2} \mathrm{PO}_{2}$ (13.7 at.\% P): (a) as-deposited and (b) after 30 min sputtering. 